\title{
KONSEP DASAR ILMU GIZI
}

\section{Muhammad Irvan}

Universitas Islam Negeri Alauddin Makassar

Email : abangvan16@gmail.com

\section{PENDAHULUAN}

Gizi atau makanan di perlukan manusia untuk pemeliharaan tubuh termasuk pertumbuhan dan pergantian jaringan yang rusak akibat kerja atau kegiatan fisik. Gizi merupakan salah satu faktor yang sangat penting dalam meningkatkan kesegaran jasmani. Keadaan gizi dikatakan baik atau normal apabila terdapat keseimbangan antara kebutuhan hidup terhadap zat-zat gizi dengan makanan yang dikonsumsi, maksudnya jumlah energi dan zat gizi yang dikonsumsi tubuh sama dengan yang dibutuhkan oleh tubuh serta sama dengan energi yang dikeluarkan dari dalam tubuh.

Setiap hari, disadari ataupun tidak kita tidak pernah bisa lepas dari zat gizi. Hal itu disebabkan karena setiap hari kita memerlukan makanan yang merupakan sumber zat gizi. Setiap kali kita merasakan lapar, pada saat itu kita memerlukan makanan untuk menghilangkan rasa lapar. Hampir setiap orang tahu pentingnya makanan bagi tubuh, tetapi pernahkah Anda memikirkan zat-zat apa yang terkandung dalam makanan yang Anda konsumsi serta bagaimana peranannya dalam menjaga kelangsungan fungsi tubuh Anda? Masih banyak orang yang belum mengerti dan mengenal komponenkomponen zat gizi serta kepentingannya bagi kesehatan tubuh. Setiap komponen zat gizi memiliki peran masing-masing bagi kelangsungan fungsi tubuh. Demi dapat memenuhi kebutuhan tersebut, seharusnya kita mampu mengenal jenis-jenis zat gizi yang diperlukan sehingga kita dapat mengonsumsi makanan secara tepat. Oleh karena itu, melalui paper ini penulis akan memaparkan materi mengenai konsep dasar ilmu gizi.

\section{PENGERTIAN ILMU GIZI}

1. Ilmu gizi (nutrition science) adalah ilmu yang mempelajari segala sesuatu tentang makanan dalam hubungannya dengan kesehatan optimal. Kata "gizi" berasal dari bahasa Arab ghidza, yang berarti "makanan". Di satu sisi ilmu gizi berkaitan dengan makanan dan di sisi lain dengan tubuh manusia. 
2. Ilmu gizi adalah ilmu yang menganalisis pengaruh pangan yang dikonsumsi terhadap organisme hidup.

3. Ilmu gizi adalah ilmu yang mempelajari hubungan antara manusia dengan pangan yang dikonsumsinya, serta pengaruhnya terhadap aspek kejiwaan (psikis) dan kehidupan sosialnya, yang meliputi juga aspek fisiologis dan biokimia.

Ilmu gizi disebut juga sebagai ilmu pangan, zat-zat gizi dan senyawa lain yang terkandung dalam bahan pangan. Reaksi, interaksi serta keseimbangannya yang dihubungkan dengan kesehatan dan penyakit. Selain itu meliputi juga proses-proses pencernaan pangan, serta penyerapan, pengangkutan, pemanfaatan dan ekskresi zat-zat oleh organisme. Zat Gizi (nutrients) adalah ikatan kimia yang diperlukan tubuh untuk melakukan fungsinya, yaitu menghasilkan energi, membangun dan memelihara jaringan serta mengatur proses-proses kehidupan.

Secara klasik kata gizi hanya dihubungkan dengan kesehatan tubuh, yaitu untuk menyediakan energi, membangun dan memelihara jaringan tubuh, serta mengatur proses-proses kehidupan dalam tubuh. Tetapi, sekarang kata gizi mempunyai pengertian lebih luas. Disamping untuk kesehatan, gizi dikaitkan dengan potensi ekonomi seseorang, karena gizi berkaitan dengan perkembangan otak, kemampuan belajar dan produktivitas kerja. Oleh Karena itu, Di Indonesia yang sekarang sedang membangun, faktor gizi di samping faktor lain dianggap penting untuk memacu pembangunan, khususnya berkaitan dengan pengembangan sumber daya manusia berkualitas.

\section{JENIS-JENIS ZAT GIZI}

Gizi yang dibutuhkan seseorang terdiri dari zat gizi makro dan zat gizi mikro. Yang termasuk kelompok zat gizi makro yaitu karbohidrat, lemak dan protein, selain itu air juga termasuk bagian dari zat gizi makro karena air juga dibutuhkan dalam jumlah yang banyak dibandingkan zat gizi lainnya, sedangkan zat gizi mikro yaitu vitamin dan mineral

\section{Zat Gizi Makro}

\section{a. Karbohidrat}

Karbohidrat yaitu senyawa organik terdiri dari unsur karbon $(\mathrm{C})$, hidrogen $(\mathrm{H})$, dan oksigen(O). Karbohidrat banyak terdapat pada tumbuhan dan binatang. Pada tumbuhan 
sintesis $\mathrm{CO} 2+\mathrm{H} 2 \mathrm{O}$ akan menghasilkan amilum / Ilmu Gizi 6 selulosa melalui proses fotosintesis. Banyak sekali makanan yang kita makan sehari-hari adalah sumber karbohidrat seperti : nasi/ beras, singkong, umbi-umbian, gandum, sagu, jagung, kentang, dan beberapa buah-buahan lainnya.

Adapun fungsi karbohidra yaitu : 1) Sebagai Sumber Energi Fungsi utama karbohidrat. 2) Sebagai Pemberi Rasa Manis pada Makanan. 3). Sebagai Penghemat Protein Bila kebutuhan karbohidrat makanan tidak mencukupi. 4). Sebagai Pengatur Metabolisme Lemak. 5). Membantu Pengeluaran Feses

\section{b. Protein}

Protein adalah suatu zat yang dalam susunan kimiawinya terdiri dari unsur Oksigen $(\mathrm{O})$, Karbon $(\mathrm{C})$, Hidrogen $(\mathrm{H})$ dan Nitrogen $(\mathrm{N})$ serta kadang-kadang mengandung sulfur (S) dan Posfor (P) yang membentuk unit-unit asam amino. Asam amino essensial ada sembilan jenis yang diperlukan manusia untuk pertumbuhan dan pemeliharaan jaringan tubuh, yaitu : leusin, isoleusin, valin, triptofan, fenilalanin, metionin, treonin, lisin, histidin. Sedangakan asam amino non essensial ada sebelas jenis, dan masih dibagi menjadi dua, yaitu asam amino essensial bersyarat dan asam amino yang benar-benar tidak essensial, diantaranya : prolin, serin, arginin, tirosin, sistein, glisin, alanin, asam glutamate, glutamine, asam aspartat, dan asparagin.

Protein mempunyai fungsi sebagai berikut :1) Enzim, Semua enzim yang teah diamati sampai saat ini adalah protein dan aktivitas katalitiknya bergantung pada integritas strukturnya sebagai protein. Enzim mempunyai berat molekul 12.000-lebih dari 1.000.000, karena itu enzim berukuran amat besar dibanding dengan substrat atau gugus fungsional. 2) Protein Transpor: Hemoglobin dan Mioglobin. Protein yang terdapat pada hemoglobin dan mioglobin berfungsi dalam pengikatan oksigen, pengangkutan oksigen dan fotosintesis. Hemoglobin juga mengangkut $\mathrm{H}+$ dan $\mathrm{CO} 2$. Selain membawa oksigen dari paru-paru ke jaringan, hemoglobin juga membawa $\mathrm{H}+$ dan $\mathrm{CO} 2$ dari jaringan ke paru-paru dan ginjal untuk dieksresikan. Dalam sel, bahan bakar organic dioksidasi oleh mitokondria membentuk $\mathrm{CO} 2$, air dan zat- lain. Pembentukan $\mathrm{CO} 2$ meningkatkan kadar $\mathrm{H}+$ di dalam jaringan karena hidrasi $\mathrm{CO} 2$ menghasilkan $\mathrm{H} 2 \mathrm{CO} 3$, suatu asam lemah yang terdisosiasi membentuk $\mathrm{H}+$ dan HCO3- . 3) Protein Pengatur: Hormon, Hormon adalah hasil sekresi kelenjar-kelenjar spesifik yang akan bekerja pada sel-sel di dekatnya dalam suatu jaringan 
tertentu, di samping pada sel di mana dia disintesis. Contohnya : Hormon Pertumbuhan, Insulin, Paratiroid Hormon . 4)Protein Kontraktil. Banyak protein yang berperan sebagai filamen, kabel, lembaran penyanggah untuk memberikan struktur biologi atau kekuatan. Massa serat otot yang segar disusun 75\% dari air dan lebih dari 20\% protein. Dua protein utama otot adalah aktin dan miosin. 5) Protein Struktural . $\alpha$-Keratin adalah protein serat utama yang dibuat oleh sel epidermis. Keratin memberikan perlindungan eksternal bagi vertebrata. Protein ini menyusun hampir seluruh berat kering dari rambut, wol, sayap, kuku, cakar, duri, sisik, tanduk, kuku kuda, kulit penyu. Fibrinogen dan Trombin adalah protein yang terlibat dalam proses hemostatis. Hemostatis adalah peristiwa penghentian perdarahan yang terjadi setelah terputusnya keutuhan vaskuler. 6) Protein Nutrien dan Penyimpan. Protein nutrien dan penyimpan terdapat pada: Biji tumbuhan menyimpan protein nutrient yang dibutuhkan untuk pertumbuhan embrio tanaman. Contohnya: protein biji gandum, jagung, dan beras, albumin, protein nutrient pada putih telur, Kasein, protein utama pada susu

\section{c. Lemak}

Lemak terdiri dari: asam lemak (fatty acid) dan gliserol. Satu molekul gliserol + 3 mol asam lemak akan menghasilkan 1 molekul trigliserida/lemak + air. Bila atom $\mathrm{C}$ yang berikatan tunggal disebut lemak jenuh (asam palmitat, stearat dalam gajih). Atom $\mathrm{C}$ yang berikatan ganda disebut asam lemak tak jenuh tunggal (asam oleat pada minyak Zaitun) dan tak jenuh ganda (asam Linoleat pada minyak kedelei dan jagung). Proses hidrogenasi adalah perubahan lemak dari tak jenuh menjadi jenuh, contoh produksi margarin dari proses hidrogenasi minyak kelapa sawit, minyak jagung, dan kedelei. Ransiditas (sifat 28 tengik) disebabkan oleh pembebasan asam lemak bebas yang memiliki bau tak enak, akibat terpaparnya lemak oleh oksigen di udara. Vitamin E merupakan nutrien penting untuk mencegah oksidasi tersebut. Lemak tak jenuh akan lebih mudah teoksidasi yang menyebabkan tengik. Asam lemak essensial merupakan asam lemak yang diperlukan dan tidak dapat disintesa oleh tubuh, antara lain asam linoleat, linolenat, dan arakidonat.

Lemak nabati (mengandung asam lemak tak jenuh titik cair) contoh: kacang tanah, biji jagung, biji kapas, kelapa. Lemak hewani (mengandung asam lemak jenuh, rantai karbon panjang) contoh: babi, sapi, kambing, ayam, telur. 
Lemak membantu transportasi dan absorpsi vitamin larut lemak yaitu A, D, E, K. Sebagai pelumas, lemak membantu menge-luarkan sisa makanan. Menghemat protein. Lemak menghemat penggu-naan protein untuk sintesis protein, sehingga protein tidak digunakan sebagai sumber energi. Pelindung organ. Lapisan lemak yang menyelubungi organ seperti jantung, hati dan ginjal membantu 30 menahan organ-organ tersebut tetap ditempatnya dan melindungi terhadap benturan dan bahaya lain. Memelihara suhu tubuh. Lapisan lemak dibawah kulit mengisolasi tubuh dan mencegah kehilangan panas tubuh secara cepat dengan demikian lemak berfungsi juga dalam memelihara suhu tubuh.

\section{d. Air}

Air atau cairan tubuh merupakan bagian utama tubuh, 55-60\% dari berat badan orang dewasa atau $75 \%$ pada bayi merapan cairan tubuh. Semakin bertambah umur cairan tubuh semakin berkurang, dan cairan tubuh laki-laki lebih banyak dari wanita karena kandungan otot tubuh lebih banyak begitu juga dengan atlet. Cairan tubuh merupakan media semua reaksi kimia di dalam sel. Cairan tubuh terdiri dari cairan intraseluler dan cairan ekstra selular.

Fungsi air dalam proses tubuh adalah 1) Pelarut dan alat angkut zat-zat gizi , 2) Katalisator dalam berbagai reaksi biologik, 3) Fasilitator pertumbuhan, 4) Pengatur suhu tubuh, dan 5) Peredam benturan organ-organ tubuh. Keseimbangan cairan tubuh adalah keseimbangan antara jumlah cairan yang masuk dan keluar tubuh. Melalui mekanisme ini jumlah cairan tubuh akan selalu konstan, kekurangan cairan akan menyebabkan dehidrasi sebaliknya kelebihan cairan akan menyababkan intoksikasi air.

\section{Zat Gizi Mikro}

\section{a. Vitamin}

Vitamin adalah senyawa organik yang tersusun dari karbon, hidrogen, oksigen, dan terkadang nitrogen atau elemen lain yang dibutuhkan dalam jumlah kecil agar metabolisme, pertumbuhan dan perkembangan berjalan normal. Jenis nutrien ini merupakan zat-zat organik yang dalam jumlah kecil ditemukan pada berbagai macam makanan. Vitamin tidak dapat digunakan untuk menghasilkan energi .

\section{b. Mineral}

Mineral merupakan bagian dari tubuh yang memegang peranan penting dalam pemeliharaan fungsi tubuh, baik pada tingkat sel, jaringan organ maupun fungsi tubuh 
secara keseluruhan . Mineral merupakan komponen inorganik yang terdapat dalam tubuh manusia. Sumber paling baik mineral adalah makanan hewani, kecuali magnesium yang lebih banyak terdapat di alam makanan nabati. Hewan memperoleh mineral dari tumbuhtumbuhan dan menumpuknya di jaringan tubuhnya. Disamping itu mineral berasal dari makanan hewani mempunyai ketersediaan biologik lebih tinggi daripada yang berasal dari makanan nabati, Makanan hewani mengandung lebih sedikit bahan pengikat mineral daripada makanan nabati. Sumber makan dari kalisum adalah tulang lunak, keju, susu, molasse, yogurt, padi-padian utuh, kacang, polong-polongan dan sayuran berdaun hijau. Menurut jenisnya, mineral dibedakan menjadi 1) Mineral Organik yaitu mineral yang dibutuhkan serta berguna bagi tubuh kita, yang dapat kita peroleh melalui makanan yang kita konsumsi setiap hari seperti nasi, ayam, ikan, telur, sayur-sayuran serta buah-buahan, atau vitamin tambahan.2) Mineral anorganik yaitu mineral yang tidak dibutuhkan serta tidak berguna bagi tubuh kita.Contohnya:Timbal Hitam $(\mathrm{Pb})$, Iron Oxide (Besi Teroksidasi), Mercuri, Arsenik, Magnesium, Aluminium atau bahan-bahan kimia hasil dari resapan tanah dan lain.

Fungsi utama kalsium yaitu : a) Mengatur pembekuan darah. Bila terjadi luka, ion kalsium di dalam darah merangsang pembebasan fosfolipida tromboplastin dari platelet darah yang terluka. Tromboplastin ini mengkatalisis perubahan protrombin, bagian darah normal, menjadi trombin. Trombin kemudian membantu perubahan fibrinogen, bagian lain dari darah, mejadi fibrin yang merupakan gumpalan darah. b) Pembentukan tulang dan gigi, c) Memelihara irama jantung, d) Permeabilitas membran selKemungkinan dengan bertindak sebagai stabilitasator membran, dan transmisi ion melalui organel sel.e) Pertumbuhan dan kontraksi ototPada waktu otot berkontraksi kalsium berperan dalam interaksi protein di dalam otot, yaitu aktin dan myosin. Bila darah kalsium kurang dari normal, otot tidak bisa mengendur sesudah kontraksi. Tubuh akan kaku dan dapat menimbulkan kejang. f) Transmisi impuls saraf.

\section{PENYEBAB GANGGUAN GIZI}

Ditinjau dari penyebabnya, gangguan gizi bisa dibagi menjadi penyebab dari faktor primer dan penyebab dari faktor sekunder. Baiklah, sekarang apakah yang disebut faktor primer itu ?, faktor primer maksudnya semua masalah gizi yang disebabkan susunan makanan salah, baik 
dalam hal kuantitas maupun kualitasnya. Faktor primer ini dapat meliputi; kurangnya penyediaan pangan, kurang baiknya distribusi pangan, kemiskinan, ketidaktahuan, dan kebiasaan makan salah. Jadi faktor yang menyebabkan tidak tersedianya makanan yang akan dimakan mulai dari hulu sampai hilir. Berikut ini adalah penyebab faktor sekunder meliputi semua faktor yang menyebabkan zat-zat gizi tidak sampai di sel-sel tubuh setelah makanan dikonsumsi, meliputi aspek; 1) anatomi, contohnya pasien yang kelainan kongenital rongga mulut, tumor daerah esofagus, dan kelumpuhan otot pengunyah pada stroke; 2) absorbsi, misalnya pasien malabsorbsi, pasien yang mengalami infeksi usus halus (Thypus Abdominalis), dan pasien post operasi pencernaan; 3) metabolisme/utilisasi, misalnya pada pasien Diabetes Mellitus yang kekurangan insulin; 4) ekskresi, misalnya pasien yang tidak mampu mengeluarkan sisa hasil metabolisme makanan; dan 5) obat-obatan misalnya pasien yang mengonsumsi obat yang berinteraksi dengan makanan sehingga zat gizi tertentu tidak bisa diserap

\section{PROSES PENCERNAAN MAKANAN}

Proses pencernaan makanan dilakukan oleh sistem pencernaan, silahkan mengingat kembali anatomi fisiologi dari sistem pencernaan. Proses ini meliputi pencernaan secara mekanik yang dilakukan oleh otot pengunyah, gigi, lidah, gerakan peristaltik saluran cerna yang membantu memecah makanan yang kita makan menjadi partikel yang lebih kecil selain itu juga dibantu dengan pencernaan kimiawi yang dilakukan oleh enzim-enzim pencernaan yang memecah karbohidrat dalam makanan menjadi bentuk karbohidrat yang paling sederhana yaitu monosakarida, memecah protein menjadi asam amino dan memecah lemak menjadi asam lemak dan gliserol. Setelah makanan dicerna menjadi bentuk yang paling sederhana, maka partikel zat gizi yang terbentuk mengalami penyerapan atau absorbsi. Absorbsi zat gizi dimulai di lambung sampai usus, absorbsi zat gizi dapat melalui cara; 1) pasif yaitu zat gizi berpindah dari saluran cerna ke pembuluh darah karena adanya perbedaan tekanan atau konsentrasi; 2) aktif yaitu zat gizi diserap dengan menggunakan energi; 3) fasilitatif misalnya menggunakan protein; dan 4) fagositosis/pinositosis yaitu membran sel epitel menfagosite partikel zat gizi. Kemudian zat gizi ini didistribusikan ke sel-sel diseluruh tubuh dan dimanfaatkan oleh tubuh. Nah bagaimanakah bisa timbul masalah kurang gizi?. Proses sampai timbulnya gejala klinis yang dirasakan oleh pasien merupakan proses yang panjang, untuk lebih jelasnya, perhatikan gambar dibawah ini : 
jadi, masalah gizi disebabkan oleh faktor primer dan sekunder yang ada, baik secara tunggal ataupun keduanya menyebabkan deplesi jaringan. Adanya deplesi zat gizi yang terus menerus dapat diketahui melalui indikator terjadinya perubahan biokimia . Cara mengetahui perubahan biokimia ini misalnya dengan pemeriksaan laboratorium ( $\mathrm{Hb}$, serum albumin, serum ferritin). Bila keadaan deplesi zat gizi terus berlanjut akan menyebabkan perubahan fungsional, dan terakhir akan terjadi perubahan anatomis.

Dampak kekurangan gizi bagi tubuh antara lain adalah; 1) tidak tersedianya sumber energi untuk produksi tenaga; 2) terganggunya atau terhambatnya pertumbuhan pada anak dan remaja; 3) menurunnya sistem pertahanan tubuh karena bahan baku sistem pertahanan adalah zat gizi yaitu protein dan air; 4) terganggunya struktur dan fungsi otak, serta,; 5) berdasarkan hasil penelitian ternyata kurang gizi kronis dapat menimbulkan perubahan perilaku menjadi anti sosial. Keadaan kurang gizi ini pada anak-anak dikenal dengan penyakit Kurang Kalori Protein (KKP) atau Marasmus dan Kwashiorkor. Itu kalau terjadi kurang gizi, sekarang bagaimana kalau kita kelebihan zat gizi?, ternyata kelebihan gizi juga berdampak negatif yaitu dapat menyebabkan obesitas yang meningkatkan risiko timbulnya penyakit degeneratif seperti diabetes mellitus, hipertensi, penyakit jantung koroner, penyakit hati dan kantung empedu. Selain penyakit akibat gizi kurang dan gizi lebih, penyakit yang berkaitan dengan gizi adalah penyakit metabolik bawaan, dan penyakit keracunan makanan.

Setelah memahami konsep dasar dalam ilmu gizi, sekarang kita akan membahas tentang kebutuhan zat gizi. Sebelum itu marilah kita pahami bahwa kebutuhan zat gizi terdiri dari: 1) kebutuhan minimal zat gizi harian/ minimal daily requirement (MDR) yang terdiri dari MDR pada saat sehat disebut sebagai MDR preventif, yaitu kebutuhan zat gizi minimal yang dibutuhkan tubuh agar tidak jatuh sakit, dan MDR pada saat sakit yang disebut sebagai MDR terapeutik yaitu jumlah zat gizi minimal yang dibutuhkan tubuh untuk sembuh;2) angka kecukupan gizi yang dianjurkan (AKG) merupakan tingkat konsumsi zat-zat gizi esensial yang dinilai cukup untuk memenuhi kebutuhan gizi hampir semua orang sehat. Untuk menentukan AKG perlu diperhatikan faktor-faktor yang berpengaruh pada AKG yaitu; tingkat kesehatan gizi masyarakat yang akan dicapai, tingkat ekonomi masyarakat, umur kelompok, jenis kelamin, aktivitas fisik, dan kondisi fisik khusus (misalnya hamil/menyusui). Kebutuhan zat gizi pada AKG merupakan angka kebutuhan zat gizi rata-rata pada kelompok umur menurut jenis kelamin secara umum. Secara spesifik kebutuhan zat gizi setiap individu sangatlah bervariasi. Sebagai 
pedoman bagi masyarakat dalam mencapai gizi seimbang telah ditetapkan Pedoman Umum Gizi Seimbang (PUGS) yang merupakan pedoman dasar tentang gizi seimbang yang disusun sebagai penuntun perilaku konsumsi makanan dimasyarakat secara baik \& benar. Anjuran sumber energi menurut PUGS adalah $60-75 \%$ sumber energi berasal dari karbohidrat, 10-15\% sumber energi berasal dari protein, dan 10-25\% sumber energi yang berasal dari lemak 


\section{DAFTAR PUSTAKA}

1. Alam , S., \& Karini, T.A. (2020). Islamic Parenting” Pola Asuh Anak : Tinjauan Perspektif Gizi Masyarakat”.

2. Furkon, L. A. (2014). Mengenal Zat Gizi. Ilmu Kesehatan Gizi, 1-53.http://repository.ut.ac.id /4335/2/PEBI4424-M1.pdf

3. Mardalena, I., \& Suyani, E. (2016). Keperawatan Ilmu Gizi. Kementerian Kesehatan Republik Indonesia, 182.

4. Rahayu, A., Fahrini, Y., \& Setiawan, M. I. (2019). Dasar-dasar Gizi. Yogyakarta.cv mine.

5. Ruslan, \& Aswan, M. A. (2019). Ilmu Gizi Teori \& Aplikasi Dalam Olahraga. 1-117.

6. Sediaoetama, achmad djaeni. (2008). Ilmu Gizi 1. 